\title{
Carbapenemase-Producing Enterobacteriaceae and Nonfermentative Bacteria, the Philippines, 2013-2016
}

\section{John Mark Velasco, Maria Theresa Valderama, Trent Peacock, ${ }^{1}$ Nirdnoy Warawadee, Kathyleen Nogrado, Fatima Claire Navarro, Domingo Chua, Jr., Srijan Apichai, Ruekit Sirigade, Louis R. Macareo, Brett Swierczewski}

\author{
Author affiliations: US Army Medical Directorate-Armed Forces \\ Research Institute of Medical Sciences, Bangkok, Thailand \\ (J.M. Velasco, M.T. Valderama, T. Peacock, N. Warawadee, \\ K. Nogrado, S. Apichai, R. Sirigade, L.R. Macareo, \\ B. Swierczewski); V. Luna Medical Center, Quezon City, the \\ Philippines (F.C. Navarro, D. Chua, Jr.)
}

DOI: https://doi.org/10.3201/eid2309.161237

During 2013-2016, we isolated bla ${ }_{\mathrm{NDM}^{-}}$and bla ${ }_{\mathrm{VIM}}$-harboring Enterobacteriaceae and nonfermentative bacteria from patients in the Philippines. Of 130 carbapenem-resistant isolates tested, 45 were Carba NP-positive; 43 harbored $b / a_{\mathrm{NDM}}$, and 2 harbored bla $\mathrm{VIM}_{\mathrm{V}}$. Multidrug-resistant microbial pathogen surveillance and antimicrobial drug stewardship are needed to prevent further spread of New Delhi metallo$\beta$-lactamase variants.

$\mathrm{C}$ arbapenemase-producing Enterobacteriaceae can efficiently hydrolyze carbapenems and most $\beta$-lactam drugs. Since the identification of New Delhi metallo- $\beta$ lactamase-1 (NDM-1) in 2008 (1), there has been great concern regarding the spread of the Ambler class B metallo- $\beta$-lactamases (MBLs). Confirmed infections with MBL-positive bacteria are rarely identified in the Philippines, but bla $_{\mathrm{IMP}}$-harboring Enterobacteriaceae were reported in 2014 (2), an Escherichia coli (sequence type [ST] 131) isolate harboring $b l a_{\mathrm{NDM}-1}$ was reported in 2014 (3), and 2 Klebsiella pneumoniae (ST626 and ST903) isolates harboring $b l a_{\mathrm{NDM}-1}$ and $b l a_{\mathrm{NDM}-7}$ genes were reported in 2016 (4).

We performed isolate identification and antimicrobial drug susceptibility testing by using the MicroScan WalkAway 40 plus System (Beckman Coulter, Brea, CA, USA) on 1,516 gram-positive and gram-negative isolates from patients admitted to various wards in the V. Luna Medical Center, a tertiary-care military hospital in Manila, the Philippines, during August 2013-April 2016. To better

${ }^{1}$ Current affiliation: US Army Institute of Surgical Research, Fort Sam Houston, Texas, USA. assess the distribution of carbapenem resistance and the underlying molecular mechanisms of resistance, we selected gram-negative isolates with imipenem or meropenem (or both) MICs of $\geq 8 \mu \mathrm{g} / \mathrm{mL}$. We used microbroth dilution susceptibility testing (5) to select and verify 130 gram-negative nonrepeat isolates (i.e., each isolate was tested once) and then tested the isolates for carbapenemase production by using the Carba NP test as previously described (6). We tested all isolates with a Carba NP-positive result for $b l a_{\mathrm{NDM}}$ and $b l a_{\mathrm{KPC}}$ by using a multiplex real-time PCR assay as previously described $(7,8)$; isolates with PCR-negative results were further tested, using the Xpert Carba-R PCR test with the GeneXpert IV System (both from Cepheid, Sunnyvale, CA, USA), for the presence of $b l a_{\mathrm{NDM}}, b l a_{\mathrm{KPC}}$, $b l a_{\mathrm{VIM}}, b l a_{\mathrm{IMP}-1}$, and $b l a_{\mathrm{OXA}-48}$.

Of the 130 bacterial isolates tested, $45(35 \%)$ had positive Carba NP test results and $43(33 \%)$ harbored $b l a_{\mathrm{NDM}}$; $25(58 \%)$ of the $b l a_{\mathrm{NDM}^{-}}$-carrying isolates were identified as K. pneumoniae (online Technical Appendix Table, https:// wwwnc.cdc.gov/EID/article/23/9/16-1237-Techapp1.pdf). None of the isolates was positive for bla ${ }_{\mathrm{KPC}}$. Two Pseudomonas aeruginosa isolates that had positive Carba NP test results were negative for $b l a_{\mathrm{NDM}}$ and $b l a_{\mathrm{KPC}}$ but positive for $b l a_{\mathrm{VIM}}$. During the collection period, we also tested 8 environmental samples collected from the hospital's neonatal intensive care unit and obstetrics and gynecology wards; 3 $(38 \%)$ of the 8 isolates were positive for $b l a_{\mathrm{NDM}}$ and identified as K. pneumoniae (online Technical Appendix Table).

We report the identification of $b l a_{\mathrm{NDM}}$-positive bacterial isolates in several genera of Enterobacteriaceae and nonfermentative bacteria in the Philippines. This finding is particularly significant because NDM-like enzymes have a broad range of activity against most $\beta$-lactam antimicrobial drugs and are often associated with serious clinical infections (9). A higher risk for plasmid-mediated transfer of NDM-1 exists through conjugation between different gramnegative bacterial strains (10), and NDM-1 can spread rapidly via nosocomial transmission or community-acquired infection. Furthermore, although limited in number, the environmental samples in this study were also positive for $b l a_{\mathrm{NDM}}$, which suggests the possibility of nosocomial transmission and local circulation.

We conducted multiplex real-time PCR testing only for $b l a_{\mathrm{NDM}}, b l a_{\mathrm{KPC}}, b l a_{\mathrm{VIM}}, b l a_{\mathrm{IMP}-1}$, and $b l a_{\mathrm{OXA}-48}$ and did not investigate clonality; thus, further investigation into other carbapenemase genes should be conducted. In addition, further experiments should be performed to characterize the plasmids carrying the carbapenemase genes. Strengthening of multidrug-resistant microbial pathogen surveillance and antimicrobial drug stewardship is urgently needed to better characterize drug-resistance patterns and improve early detection and containment strategies in developing countries. 


\section{Acknowledgments}

We thank Bryony Soltis and the Bacteriology Section and Department of Research and Training of V. Luna Medical Center, Armed Forces of the Philippines Health Service Command, for their support.

This study was funded by a grant from the Armed Forces Health Surveillance Center-Global Emerging Infections Surveillance and Response System.

The views expressed in this article are those of the authors and do not reflect the official policy of the Department of the Army, the Department of Defense, or the US Government.

Dr. Velasco is the regional clinical investigator of the Department of Virology, Armed Forces Research Institute of Medical Sciences. His primary research interests include detection and control of emerging pathogens, epidemiology of respiratory and arthropodborne viruses, and microbial typing of multidrug-resistant bacteria.

\section{References}

1. Yong D, Toleman MA, Giske CG, Cho HS, Sundman K, Lee K, et al. Characterization of a new metallo- $\beta$-lactamase gene, $b l a_{\mathrm{NDM}-1}$, and a novel erythromycin esterase gene carried on a unique genetic structure in Klebsiella pneumoniae sequence type 14 from India. Antimicrob Agents Chemother. 2009;53:5046-54. http://dx.doi.org/ 10.1128/AAC.00774-09

2. Peirano G, Lascols C, Hackel M, Hoban DJ, Pitout JD. Molecular epidemiology of Enterobacteriaceae that produce VIMs and IMPs from the SMART surveillance program. Diagn Microbiol Infect Dis. 2014;78:277-81. http://dx.doi.org/ 10.1016/j.diagmicrobio.2013.11.024

3. Peirano G, Bradford PA, Kazmierczak KM, Badal RE, Hackel M, Hoban DJ, et al. Global incidence of carbapenemase-producing Escherichia coli ST131. Emerg Infect Dis. 2014;20:1928-31. http://dx.doi.org/10.3201/eid2011.141388

4. Chou A, Roa M, Evangelista MA, Sulit AK, Lagamayo E, Torres BC, et al. Emergence of Klebsiella pneumoniae ST273 carrying $b l a_{\mathrm{NDM}-7}$ and ST656 carrying bla $a_{\mathrm{NDM}-1}$ in Manila, Philippines. Microb Drug Resist. 2016;22:585-8. http://dx.doi.org/10.1089/mdr.2015.0205

5. Clinical and Laboratory Standards Institute. Performance standards for antimicrobial susceptibility testing: twenty-fifth informational supplement (M100-S25). Wayne (PA): The Institute, 2015.

6. Nordmann P, Poirel L, Dortet L. Rapid detection of carbapenemase-producing Enterobacteriaceae. Emerg Infect Dis. 2012;18:1503-7. http://dx.doi.org/10.3201/eid1809.120355

7. Milillo M, Kwak YI, Snesrud E, Waterman PE, Lesho E, McGann P. Rapid and simultaneous detection of $b l a_{\mathrm{KPC}}$ and $b l a_{\mathrm{NDM}}$ by use of multiplex real-time PCR. J Clin Microbiol. 2013;51:1247-9. http://dx.doi.org/10.1128/JCM.03316-12

8. Milillo M, Kwak YI, Snesrud E, Waterman PE, Lesho E, McGann P. Correction for Milillo et al., Rapid and simultaneous detection of blaKPC and blaNDM by use of multiplex real-time PCR. J Clin Microbiol. 2015;53:1460. http://dx.doi.org/10.1128/ JCM.00373-15

9. Schwaber MJ, Klarfeld-Lidji S, Navon-Venezia S, Schwartz D, Leavitt A, Carmeli Y. Predictors of carbapenem-resistant Klebsiella pneumoniae acquisition among hospitalized adults and effect of acquisition on mortality. Antimicrob Agents Chemother. 2008;52:1028-33. http://dx.doi.org/10.1128/AAC.01020-07
10. Kulkova N, Babalova M, Sokolova J, Krcmery V. First report of New Delhi metallo- $\beta$-lactamase-1-producing strains in Slovakia. Microb Drug Resist. 2015;21:117-20. http://dx.doi.org/10.1089/ mdr.2013.0162

Address for correspondence: John Mark Velasco, Department of Virology, Armed Forces Research Institute of Medical Sciences, 315/6 Rajvithi Rd, Bangkok 10400, Thailand; email: John.Velasco.ca@afrims.org

\section{Chronic Wasting Disease Prion Strain Emergence and Host Range Expansion}

\author{
Allen Herbst, ${ }^{1}$ Camilo Duque Velásquez, ${ }^{1}$ \\ Elizabeth Triscott, Judd M. Aiken, \\ Debbie McKenzie
}

Author affiliation: University of Alberta, Edmonton, Alberta, Canada

DOI: https://doi.org/10.3201/eid2309.161474

Human and mouse prion proteins share a structural motif that regulates resistance to common chronic wasting disease (CWD) prion strains. Successful transmission of an emergent strain of CWD prion, $\mathrm{H}^{+} 5^{+}$, into mice resulted in infection. Thus, emergent CWD prion strains may have higher zoonotic potential than common strains.

$\mathrm{C}$ hronic wasting disease (CWD) is a contagious prion disease of cervids that is spreading globally. CWD is enzootic in multiple cervid species, including deer and elk; the major foci of disease are Colorado/Wyoming (USA), Wisconsin/Illinois (USA), and Alberta/Saskatchewan (Canada). CWD is also present in captive cervids in South Korea and wild reindeer and moose in Norway (https://www.nwhc. usgs.gov/images/cwd/cwd_map.jpg). CWD results from the conformational transformation of the host-encoded cellular prion protein $\left(\mathrm{PrP}^{\mathrm{C}}\right)$ into protease-resistant, detergent-insoluble, $\beta$-sheet rich, amyloidogenic conformers, termed prions $\left(\mathrm{PrP}^{\mathrm{CWD}}\right)$. Within their conformation, prion strains encipher the information that directs the templated misfolding and aggregation of $\mathrm{PrP}^{\mathrm{C}}$ molecules into additional prions (1).

Although the sequence homology of PrP among mammals is high, the ability of particular prion strains to cause disease in different species is determined by the conformational compatibility between a given strain and the host $\operatorname{PrP}^{\mathrm{C}}(2)$. We ${ }^{1}$ These authors contributed equally to this article. 